\title{
Hospital-Acquired Pneumonia in a Multipurpose Intensive Care Unit: One-Year Prospective Study
}

\author{
Pneumonia Adquirida no Hospital num Serviço \\ de Medicina Intensiva: Estudo Prospectivo com \\ Um Ano de Seguimento
}

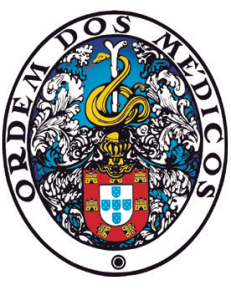

Rui Dias COSTA 1 , João Pedro BAPTISTA $\triangle^{2}$, Ricardo FREITAS ${ }^{2}$, Paulo Jorge MARTINS ${ }^{2}$

Acta Med Port 2019 Dec;32(12):746-753 - https://doi.org/10.20344/amp.11607

\begin{abstract}
Introduction: Hospital-acquired pneumonia continues to be a frequent complication in the intensive care unit and an important cause of admission in the intensive care unit. The aim of our study was to evaluate the demography, incidence, risk factors, causative bacterial pathogens and outcome of all episodes of Hospital-acquired pneumonia in our unit.

Material and Methods: Prospective observational study, at a tertiary university hospital during one year (2014) including all the cases of hospital-acquired pneumonia in the intensive care unit.

Results: Sixty patients were identified with pneumonia. Thirty-five (58.3\%) had an intensive care unit acquired pneumonia, corresponding to 6.9 cases $/ 1000$ intubation-days. Antibiotic treatment in the previous 30 days was present in $75 \%$ of the cases. The incidence of Staphylococcus aureus, Pseudomonas aeruginosa and Acinetobacter baumannii was $26.2 \%, 20.0 \%$ and $9.2 \%$, respectively. Patients with late-onset hospital-acquired pneumonia ( $\geq 7$ days) showed higher frequency of non-fermenting Gram-negative bacilli isolates, and methicillin-resistant S. aureus. Combination therapy was performed in $67.0 \%$, and de-escalation in $18.3 \%$. The mortality rate was $18.3 \%$. The adjusted odds ratio for intensive care unit mortality in the group of patients with non-intensive care unit acquired pneumonia was $5.2(95 \% \mathrm{Cl}$ of $1.02-22.10 ; p=0.046)$.
\end{abstract}

Discussion: The knowledge of local bacterial flora and resistance patterns is of crucial importance and strongly recommended. This evidence increases the probability of success of empiric antibiotic therapy.

Conclusion: S. aureus was the predominant causative agent of nosocomial pneumonia. The most frequent risk factor identified for infection with multidrug-resistant organisms was previous treatment with antibiotics. Multidrug-resistant organisms were present in $45 \%$ of documented hospital-acquired pneumonias. In admitted patients with non-intensive care unit acquired pneumonia, the intensive care unit mortality rate was nearly five times higher compared to intensive care unit acquired pneumonia.

Keywords: Cross Infection; Drug Resistance, Multiple, Bacterial; Healthcare-Associated Pneumonia; Intensive Care Units; Pneumonia, Ventilator-Associated

\section{RESUMO}

Introdução: A pneumonia adquirida no hospital é uma complicação frequente nos doentes críticos e uma importante causa de admissão nos Cuidados Intensivos. O objetivo deste estudo foi avaliar a demografia, incidência, fatores de risco, microbiologia e outcome da pneumonia nosocomial num Serviço de Medicina Intensiva.

Material e Métodos: Estudo prospectivo e observacional, num hospital universitário terciário, durante o período de um ano (2014).

Resultados: Foram avaliados 60 doentes. Trinta e cinco $(58,3 \%)$ com pneumonia nosocomial adquirida no Serviço de Medicina Intensiva, correspondendo a 6,9 casos/1000 dias de intubação. A antibioterapia nos últimos 30 dias esteve presente em $75 \%$ dos casos. A incidência de Staphylococcus aureus, Pseudomonas aeruginosa e Acinetobacter baumannii foi de 26,2\%, 20,0\% e 9,2\% respetivamente. Os doentes com pneumonia de início tardio ( $\geq 7$ dias) apresentaram maior frequência de bacilos Gram-negativos não-fermentadores e S. aureus resistente à meticilina. A antibioterapia em associação foi aplicada em $67,0 \%$ e a descalação em $18,3 \%$ dos doentes. A taxa de mortalidade foi $18,3 \%$. O odds ratio ajustado de mortalidade no grupo de doentes críticos com pneumonia nosocomial adquirida fora da $\mathrm{UCI}$ foi de 5,2 (95\% Cl de 1,02-22,10; $p=0,046)$.

Discussão: $O$ conhecimento da flora local bacteriana e os padrões de resistência bacteriana são de grande importância e amplamente recomendados. Esta evidência aumenta a probabilidade de sucesso da antibioterapia empírica.

Conclusão: O S. aureus foi o agente causador predominante da pneumonia. O fator de risco mais frequente para infecção por organismos multirresistentes foi o tratamento prévio com antibióticos. Organismos multirresistentes estavam presentes em $45 \%$ das pneumonias adquiridas no hospital de origem bacteriana comprovada. O grupo de doentes críticos com pneumonia nosocomial não adquirida no Serviço de Medicina Intensiva apresentou um risco de mortalidade cerca de cinco vezes maior comparativamente aos doentes com pneumonia nosocomial adquirida no Serviço de Medicina Intensiva.

Palavras-chave: Farmacorresistência Bacteriana Múltipla; Infecção Hospitalar; Pneumonia Associada a Cuidados de Saúde; Pneumonia Associada à Ventilação Mecânica; Unidades de Cuidados Intensivos

\section{INTRODUCTION}

Hospital-acquired pneumonia (HAP) or nosocomial pneumonia is the second most frequent nosocomial infection. ${ }^{1,2}$ Ventilator-associated pneumonia (VAP) or intubation-associated pneumonia (IAP) is a pneumonia that arises more than $48-72$ hours after endotracheal intubation and is not incubating at the time of admission. ${ }^{3}$ Notably, VAP is associated with increased hospital stay, significant

\footnotetext{
1. Department of Internal Medicine. Centro Hospitalar Tondela-Viseu. Viseu. Portugal.

2. Department of Intensive Care. Centro Hospitalar e Universitário de Coimbra. Coimbra. Portugal.

$\triangle$ Autor correspondente: João Pedro Baptista. joaopedrobaptista@gmail.com

Recebido: 27 de novembro de 2018 - Aceite: 02 de julho de 2019 | Copyright @ Ordem dos Médicos 2019
} 
financial burden and an attributable mortality rate of $13.5 \% .{ }^{4,5}$ The success of treatment is based on early diagnosis and prompt initiation of adequate antimicrobial(s). In addition, effective antibiotic therapy must be initiated without waiting for the microbiologic results, which is more important when addressing the critically ill patient. The decision as to which empiric antibiotic treatment should be used is based on the clinical characteristics of the host, time-onset and severity of the infection to be treated. Additionally, knowledge of local bacterial flora and resistance patterns is of crucial importance and is strongly recommended by most national and international guidelines for HAP and VAP and by the European Society of Intensive Care Medicine (ESICM) and the European Society of Clinical Microbiology and Infectious Diseases (ESCMID) in collaboration with the World Alliance Against Antimicrobial Resistance (WAAAR). ${ }^{1,3,5,6}$ Indeed, such microbiological data are distinct among countries, hospitals, wards and ICUs, and the awareness of this information increases the probability of success of empiric antibiotic therapy. Although antibiotic resistance is a global issue, the adequate actions lie at national and regional levels, with special emphasis in intensive care units (ICU) — 'think globally, act locally'. Epidemiological data regarding HAP in individual Portuguese ICUs are nonexistent in the medical literature, revealing a discrepancy between the clinical and economic burden it entails, and the measures that have been undertaken to address this issue. Consequently, this makes it difficult to compare individual ICU results with the data obtained at a national level. ${ }^{7,8}$

To address this matter, the aim of our study was the investigation of epidemiologic, clinical and microbiological patterns of HAP in patients admitted to a multipurpose ICU.

\section{MATERIAL AND METHODS}

This was a prospective, observational single-centre study, conducted in 2014 and performed in a 20-bed multipurpose ICU at the Coimbra Hospital and University Centre (CHUC), Portugal. Patients were eligible if they had a diagnosis of pneumonia. Pneumonia was suspected in the presence of new or worsened radiological infiltrates associated with clinical or laboratory findings suggestive of infection: a temperature of over $38^{\circ} \mathrm{C}$ or under $36^{\circ} \mathrm{C}$, purulent respiratory secretions and a leukocyte count of over $10000 / \mathrm{mm}^{3}$ or leukopenia under $4000 / \mathrm{mm}^{3}{ }^{3}$ Potentially pathogenic microorganism(s) isolated from the respiratory tract were considered the etiologic agent if isolated within a period of 48 hours of the HAP diagnosis. ${ }^{1,9}$ Two investigators (RF and RD) independently confirmed the diagnosis of pneumonia. ${ }^{3}$ There was arbitration by a third senior investigator (JPB) whenever there was persistent disagreement. Microbiological confirmation was based on positive cultures from endotracheal aspirate(s). The collection of tracheal aspirates was performed by using 14 French siliconized polyvinyl chloride tracheal aspiration probe, introduced through the endotracheal tube until resistance was encountered and retracted approximately $2 \mathrm{~cm}$. Microbiological assessment was performed by means of qualitative methods (presence or absence of growth). Redundant isolates were ignored.

HAP was defined as pneumonia that occurs 48 hours or more after hospital admission, which was not incubating at the time of admission. ${ }^{3}$ IAP was defined as pneumonia that arises more than $48-72$ hours after endotracheal intubation. ${ }^{3}$ Incidence of pneumonia was expressed per 1000 patients with tracheal tube for at least 48 hours. Patients were evaluated prospectively from January 2014 to December 2014.

Early-onset HAP was defined as pneumonia developing $\leq 7$ days after hospital admission. ${ }^{10}$ According to Magiorakos et al, characterization of bacteria as resistant was based on in vitro antimicrobial susceptibility test results, and was classified in one of the following classes: 'multidrug-resistant' (MDR), 'extensively drug-resistant' (XDR) and 'pandrug-resistant' (PDR). A bacterial isolate that is characterized as XDR will also be characterized as MDR. ${ }^{11}$ For Gram-negative bacteria, treatment-limiting resistance to all first-line agents, i.e., all $\beta$-lactams, including carbapenems and $\beta$-lactamase inhibitor combination and fluoroquinolones, were considered as 'difficult-to-treat resistance' (DTR). ${ }^{12}$ 'De-escalation' was defined as an antimicrobial policy consisting of the initial use of wide-spectrum antimicrobials (initial empiric therapy) followed by the reassessment of treatment when culture results were available and susceptibilities of the pathogens identified. This led to a treatment modification, with fewer antibiotics and/or agents of narrower spectrum. ${ }^{13,14}$

Demographic, clinical and physiological characteristics were evaluated (severity index, comorbidity index, presence of shock or respiratory failure, serum lactate, ICU and hospital outcomes). The following risk factors (RF) for bacterial resistance were considered: prior antibiotic treatment (previous 30 days), structural lung disease, residence in assisted living facilities/nursing homes, long-term dialysis, diabetes mellitus and immunosuppression.

We defined 'structural pulmonary disease' as any condition that significantly alters the architecture of lower airway and lung parenchyma, such as: severe chronic obstructive pulmonary disease (COPD), bronchiectasis and cavities as sequelae of necrotizing diseases or pulmonary fibrosis. 'Immunosuppression' was defined as: known immunosuppressive illness (primary or acquired immunodeficiency) and/ or receiving immunosuppressive therapy like chemotherapy in the previous year and/or corticosteroids [short duration therapy with prednisolone $\geq 1 \mathrm{mg} / \mathrm{kg}$ or $>40 \mathrm{mg}$ daily (or equivalent) for at least seven days in the previous three months or long duration therapy with prednisolone $\geq 0,2 \mathrm{mg} / \mathrm{kg}$ (or equivalent) for at least three months in the previous year].

This study was approved by the Human Research Ethics Committee of Coimbra University Hospitals (CHUC115-13), which waived the need for informed consent.

\section{Statistical analysis}

Data are presented as mean and standard deviation (SD) or median and interquartile range (IQR), as 
appropriate. Differences in categorical variables were calculated using Fisher's exact test or the chi-square test, as appropriate. For subgroup comparison of independent samples, student's t-test, Mann-Whitney U-test or KruskalWallis test was used, as appropriate. A logistic regression model was developed to evaluate mortality risk and origin of HAP (ICU or out of the ICU) in multivariate analysis and the Hosmer-Lemeshow and Nagel R square statistic was used to assess goodness of fit. Statistical significance was defined as a $p$ value $<0.05$, and statistical analysis employed SPSS $®$ (IBM®, version 22, Chicago, IL, USA).

\section{RESULTS}

Sixty patients with HAP were included for detailed analysis, corresponding to $11.7 \%$ of all 531 patients admitted in the ICU in 2014. The global rate of mechanical ventilation (and endotracheal intubation) at our ICU was $98 \%$ in the same year. No patient had more than one episode of HAP during the study period. Baseline characteristics of the studied patients are represented in Table 1.

Of 60 patients, $35(58.3 \%)$ had an ICU-acquired HAP, corresponding to 6.9 cases/1000 intubation-days. In the remaining 25 patients HAP was acquired out of the ICU, which was the main reason for ICU admission and invasive mechanical ventilation. The comparison between ICU and non-ICU acquired HAP patients is displayed in Table 2.

Frequency of RF for drug resistance microorganism was distributed as follows: antibiotic treatment in the previous 30 days $(75.0 \%)$, immunosuppression $(16.7 \%)$, structural lung disease $(13.3 \%)$, diabetes mellitus (8.3\%), chronic hemodialysis $(3.3 \%)$ and residence in a nursing home or long-term care facility (1.7\%). Overall, one RF for the presence of resistant organism was present in $55.0 \%$, two in $21.7 \%$, more than two in $6.7 \%$ of patients; RF were absent in $16.7 \%$. Patients with RF had a frequency of $33.3 \%$ of non-fermenting Gram-negative bacilli (NFGNB) versus $20 \%$
Table 1 - Baseline characteristics of the 60 studied patients with HAP

\begin{tabular}{|c|c|}
\hline \\
\hline \multicolumn{2}{|l|}{$\begin{array}{l}\text { Baseline characteristics } \\
\text { Aqe y median (IQR) }\end{array}$} \\
\hline Male gender, $n, \%$ & $41(81.7)$ \\
\hline SAPS II, median (IQR) & $30(3)$ \\
\hline Mechanical ventilation, $\mathrm{n}, \mathrm{\%}$ & $60(100)$ \\
\hline Charlson score, median (IQR) & $3.1(16.2)$ \\
\hline & $24(40)$ \\
\hline Medical hospital admission, $\mathrm{n}, \%$ & $21(35)$ \\
\hline Surgical hospital admission, $n, \%$ & $15(25)$ \\
\hline Serum lactate*, mmol/L, median (IQR) & $1.1(0.4)$ \\
\hline P/F relation*, mmHg, median (IQR) & $213(27)$ \\
\hline CRP on D0, mg/dL, median (IQR) & $16.7(16.3)$ \\
\hline CRP on D1, mg/dL, median (IQR) & $20(14)$ \\
\hline CRP on D8, mg/dL, median (IQR) & $11(13)$ \\
\hline Length of stay, d, mean (SD) & $22(6)$ \\
\hline Presence of risk factor for HAP $(\geq 1) n, \%$ & $50(83.3)$ \\
\hline Diabetes mellitus n, \% & $5(8.3 \%)$ \\
\hline HAP acquired in the ICU, n, \% & $35(58.3)$ \\
\hline HAP acquired out of the ICU, n, \% & $25(41.7)$ \\
\hline Day of HAP diagnosis, median (IQR) & $9(11)$ \\
\hline Late-onset HAP (> 7d), n, \% & $34(56.7)$ \\
\hline $\begin{array}{l}\text { Patients with documented bacterial } \\
\text { infection } n, \%\end{array}$ & $40(66.6)$ \\
\hline $\begin{array}{l}\text { Patients with documented non-bacterial } \\
\text { infection } n, \%\end{array}$ & $6(10.0)$ \\
\hline ICU mortality, n, \% & $11(18.3)$ \\
\hline
\end{tabular}

Table 2 - Distinct characteristics of HAP within two categories: ICU-acquired and non-ICU acquired HAP

\begin{tabular}{|c|c|c|c|}
\hline Variable & ICU-acquired & non-ICU acquired & $p$ \\
\hline All patients $(n=60)$ & 35 & 25 & - \\
\hline $\begin{array}{l}\text { ICU length of stay, d, median (IQR) } \\
\text { SAPS II, median (IQR) } \\
\text { Age (y), median (IQR) } \\
\text { Male sex, } n, \%\end{array}$ & $\begin{array}{l}25(8) \\
28(5) \\
49(27) \\
29(83)\end{array}$ & $\begin{array}{l}13(15) \\
32(4) \\
58(21) \\
20(80)\end{array}$ & $\begin{array}{c}0.03 \\
0.001 \\
0.01 \\
1.0\end{array}$ \\
\hline $\begin{array}{l}\text { Serum lactate, } \mathrm{mmol} / \mathrm{L} \text {, median* (IQR) } \\
P / F \text { relation, } \mathrm{mmHg} \text {, mean* (SD) } \\
\text { ICU mortality, } \mathrm{n}, \%\end{array}$ & $\begin{array}{c}0.9(0.3) \\
224(107) \\
3(8.6)\end{array}$ & $\begin{array}{c}1.4(1.4) \\
162(134) \\
8(32.0)\end{array}$ & $\begin{array}{l}0.01 \\
0.07 \\
0.04\end{array}$ \\
\hline Patients with bacterial infection $(n=40)$ & 25 & 15 & - \\
\hline $\begin{array}{l}\text { NFGNB†, } \mathrm{n}, \% \\
\text { P. aeruginosa†, n, \% } \\
\text { A. baumannii†, n, \% } \\
\text { MRSA†, n, \% } \\
\text { MDR† n, \% } \\
\text { XDR n, \% }\end{array}$ & $\begin{array}{l}13(52.0) \\
10(40.0) \\
4(16.0) \\
3(12.0) \\
10(40.0) \\
7(28.0)\end{array}$ & $\begin{array}{l}5(37.5) \\
3(20.0) \\
2(13.3) \\
5(35.7) \\
8(53.3) \\
4(26.7)\end{array}$ & $\begin{array}{l}0.3 \\
0.3 \\
1.0 \\
0.1 \\
0.5 \\
1.0\end{array}$ \\
\hline
\end{tabular}

IQR: interquartile range; SD: standard deviation; SAPS: simplified acute physiology score; $P / F: P_{2} O_{2} / F_{i} O_{2}$ where $P_{3}$ is the arterial pressure and $F$ is the fraction of inspired $\mathrm{O}_{2}$; d: days; y: years; HAP: hospital-acquired pneumonia; MDR: multidrug resistant organism; NFGNB: non-fermenting Gram-negative bacilli; MRSA: methicillin-resistant Staphylococcus aureus; XDR: extra-drug resistant organism.

* Worst result on the day of diagnosis.

† Two patients (one in each sub-group) without microbiological data within the 48 hours period, as defined in the 'material and methods' section. 
Table 3 - Clinical characteristics in 60 patients with HAP, according to the number of risk factors

\begin{tabular}{lccccc}
\hline Variable & No RF & 1 RF & 2 RF & > 2RF & P \\
\hline$N$ & 10 & 33 & 13 & 4 & - \\
Age, years, med (IQR) & $31(29)$ & $53(20)$ & $64(23)$ & $69(18)$ & 0.01 \\
Length of stay, d, med (IQR) & $22(16)$ & $21(16)$ & $22(27)$ & $19(18)$ & 0.71 \\
Multiple drug resistance organisms (\%) & 40.0 & 43.5 & 44.0 & 66.7 & 0.95 \\
ICU mortality (\%) & 0 & 21.2 & 15.4 & 50.0 & 0.16 \\
\hline
\end{tabular}

D: days; ICU: intensive care unit; IQR: interquartile range; RF: risk factor.

in patients without RF. Additional characteristics of sub-categories of RF are displayed in Table 3.

Early-onset HAP ( $\leq 7$ days) was present in 26 patients (43.3\%) and late-onset HAP in the remainder (34/60-56.7\%).

A total of 65 microorganisms were identified in the 60 patients (Table 4). In two patients, microbiological data were not available within the studied period of 48 hours of the HAP diagnosis. Respiratory samples were positive in $79.3 \%$ of patients $(46 / 58)$. In six patients, a non-bacterial agent was the etiologic factor: Candida albicans $(n=4)$, Aspergillus fumigatus $(\mathrm{n}=1)$ and Influenza $A$ H1N1 virus $(n=1)$; two of these patients $(2 / 6,33.3 \%)$ were considered immunosuppressed. Polymicrobial infection (more than one microorganism as etiologic agent of NP) was documented in $28 \%$. Within the group of 40 patients with documented bacterial infection (40/58, 69\%), Staphylococcus aureus, Pseudomonas aeruginosa and Acinetobacter baumannii were the most frequent etiologic agents $(26.2 \%, 20.0 \%$ and $9.2 \%$, respectively - Table 4); NFGNB were present in $45.0 \%(18 / 40)$ and $44.4 \%$ of $S$. aureus isolates were methicillin-resistant.

Patients with late-onset HAP showed higher frequency of NFGNB isolates, compared to patients with early-onset HAP: 61.5\% (16/26) vs 14.3 (2/14), respectively $(p=0.007)$. Similarly, the frequency of methicillin-resistant Staphylococcus aureus (MRSA) was higher in patients with late-onset infection: $26.9 \%(7 / 26)$ and $7.1 \%(1 / 14)$, respectively $(p=0.22)$. Microbiological differences between ICU and non-ICU acquired HAP patients with bacterial infection $(n=40)$ are displayed in Table 2.

On a 'bacteria-based analysis', of the 59 bacterial isolates $35.6 \%(21 / 59)$ were classified as MDR and $20.3 \%(12 / 59)$ as XDR. When considering Gram-negative

Table 4 - Frequency of etiologic agents of hospital-acquired pneumonia (65 microbiological isolates in 44 of the 60 studied patients*)

\begin{tabular}{lcc}
\hline Microorganism & N & $\%$ \\
\hline Staphylococcus aureus & 17 & 26.2 \\
Pseudomonas aeruginosa & 13 & 20.0 \\
Acinetobacter baumannii & 6 & 9.2 \\
Klebsiella pneumoniae & 5 & 7.7 \\
Candida albicans & 4 & 6.1 \\
Serratia marcescens & 2 & 3.1 \\
Hemophilus influenzae & 2 & 3.1 \\
Others & 12 & 18.5 \\
\hline
\end{tabular}

* two patients without microbiologic data bacteria, 23.7\% (9/33) were classified as DTR. On a 'patientbased analysis', 40 patients with confirmed bacterial HAP, 18 patients $(45 \%)$ had an MDR as the etiologic agent, of which 11 patients $(27.5 \%)$ had an XDR. These patients showed higher length of stay (LOS), when compared with organisms considered sensible (24.5 vs 19.5 days, $p=0.19)$. PDR organisms were not present in our sample.

Piperacillin-tazobactam, vancomycin and levofloxacin were the most prescribed initial antibiotics, in $20.1 \%$, $19.5 \%$ and $18.6 \%$ of the patients, respectively. Fifty-two patients $(86.6 \%)$ received empiric antibiotic therapy, of which $35(35 / 52 ; 67 \%)$ in combination. Of these 52 patients, 40 had a positive pathogen identification (40/52; 77\%), of which $65 \%$ (26/40) showed adequate empiric treatment. De-escalation was performed in $18.3 \%$ of patients.

The global mortality was $18.3 \%$ (11 patients). Table 5 shows the differences between ICU survivors and non-survivors. Of note, non-survivors showed higher frequency of septic shock, when compared with ICU survivors (72.7 vs $55.1 \%$, respectively, $p=0.33$ ). ICU mortality within several categories is displayed in Fig. 1.

In a multivariate analysis we found an age adjusted odds ratio (OR) for ICU mortality of $5.2(95 \% \mathrm{Cl}$ of $1.02-22.10$; $p=0.046)$ in the group of patients with non-ICU acquired HAP. The Hosmer-Lemeshow test showed a $p=0.55$ and the Nagel $R$ square statistic was 0.35 , indicating a good fit of the model.

\section{DISCUSSION}

Our study showed that $58.5 \%$ (35/60) of our patients with HAP acquired the infection in the ICU, corresponding to an annual incidence of 6.9 cases $/ 1000$ intubation-days. HAP, as the cause of ICU admission, constituted an important risk for ICU mortality. In addition, the majority of studied patients had at least one risk factor for resistant bacteria. S. aureus was the most frequent etiologic agent and $45 \%$ of patients with bacterial HAP had an MDR as the etiologic agent.

In the last decade, the incidence of VAP ranged between 1.9 and 18 cases per 1000 ventilator-days in United States and Europe..$^{15}$ Surprisingly, there is a paucity of information regarding epidemiological, clinical and microbiological aspects of HAP/VAP in Portugal. In addition, to the best of our knowledge, there are no published data in the medical literature regarding incidence and microbiological characterization of HAP in an individual Portuguese adult ICU setting. On the other hand, the epidemiological surveillance of health care associated infections (HAI) in Portugal is 
Table 5 - HAP subgroup comparisons according to outcome in the ICU $(n=60)$

\begin{tabular}{lccc}
\hline Variable & Survivors & Non-Survivors & p \\
\hline $\mathrm{N}$ & 49 & 11 & - \\
Day of diagnosis, median (IQR) & $8(11)$ & $11(15)$ & 0.25 \\
Age (y), median (IQR) & $52(22)$ & $58(22)$ & 0.18 \\
Serum lactate, mmol/L, median (IQR) & $1.0(0.5)$ & $1.9(1.4)$ & 0.03 \\
P/F relation, mmHg, median (IQR) & $207(106)$ & $218(158)$ & 0.94 \\
Charlson score, median (IQR) & $3(7)$ & $10(9)$ & 0.04 \\
SAPS II, median (IQR) & $29(6)$ & $32(4)$ & 0.13 \\
Presence of shock (\%) & 55.1 & 72.7 & 0.33 \\
Early-onset HAP (\%) & 46.9 & 27.3 & 0.32 \\
Late-onset HAP (\%) & 53.1 & 72.7 & 0.32 \\
Microorganism identification (\%) & 23.1 & 17.8 & 0.69 \\
Adequate empiric therapy (\%) & 61.3 & 77.5 & 0.45 \\
\hline
\end{tabular}

IQR: interquartile range; SD: standard deviation; SAPS: simplified acute physiology score; $P / F: P_{a} O_{2} / F_{i} O_{2}$ where $P_{a}$ is the arterial pressure and $F_{i}$ is the fraction of inspired $\mathrm{O}_{2}$; y: years; HAP: hospital-acquired pneumonia.

regularly performed by a central department of the Ministry of Health, the Directorate-General for Health (Direção Geral de Saúde - DGS). In the most recent national report, the national rate of VAP/IAP in adult ICUs was 6.6/1000 intubation-days in 2017 and was 7.1/1000 intubation-days in 2014 (same year of our study). ${ }^{7,8}$ The pooled rate of VAP/IAP in Europe (10 countries included) in the year of 2014 was $10 / 1000$ intubation-days, ranging between 2.8 and 15.8 (European Centre for Disease Prevention and Control ECDC).$^{16}$ The results of our study are in line with these findings, although our reported rate is slightly lower than average: 6.9 events $/ 1000$ intubation-days.

After gathering evidence from the 60 studied patients we observed that the most common isolates were $S$. aureus, $P$. aeruginosa and $A$. baumannii - Table 4. More than one pathogen was present in $28 \%$ of the samples. These results concur with other studies, in which $S$. aureus caused $28 \%-41 \%$ of the episodes of VAP and approximately $62 \%$ of HAP in non-ventilated patients. ${ }^{17,18}$ Factors affecting pathogen incidence are host-microbial flora, prolonged antibiotic administration, and different ICU settings. Our multipurpose ICU setting is that of a tertiary hospital (a national trauma center) with high prevalence of severe trauma patients within the period of study ( $n=119 / 513,23.1 \%$ ), of which $72 \%(86 / 119)$ were neuro-critical patients. HAP is a common complication among these patients, and they are at risk for $S$. aureus colonization or infection in the ICU, particularly of MRSA. ${ }^{19}$ In the present study, $44.4 \%$ of $S$. aureus isolates were MRSA. Curiously, the percentage of MRSA in 2014 in Portugal reported by DGS (national data, based on 22 reference laboratories of microbiology) was very similar $-47.4 \%{ }^{7}$

Patients with late-onset $S$. aureus infection showed a higher rate of MRSA $(88.9 \% ; 8 / 9)$ which is in accordance with the EU-VAP/CAP study. ${ }^{15}$ This large, prospective and observational study involved 27 ICUs from Belgium, France, Germany, Greece, Italy, Ireland, Portugal, Spain, and Turkey and showed that $S$. aureus was the dominant

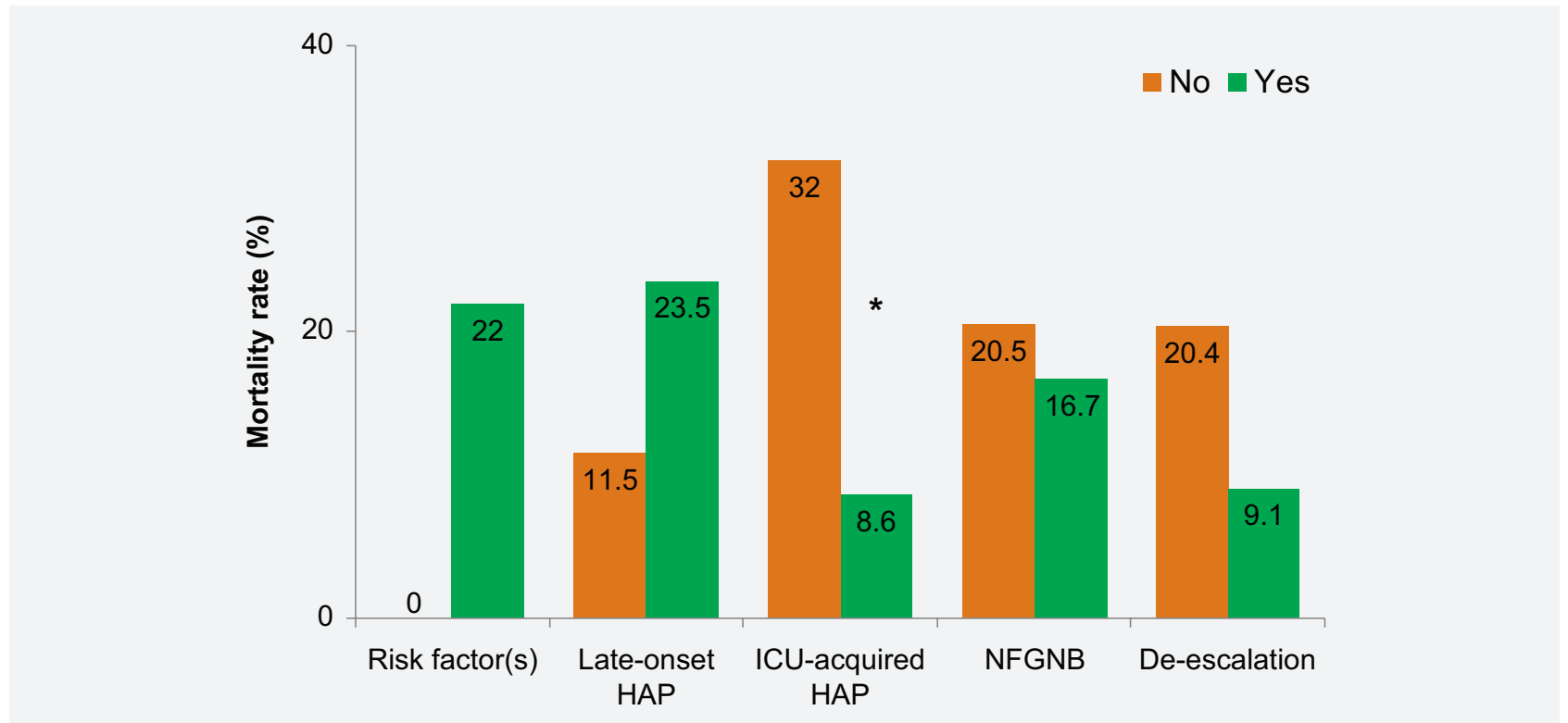

Figure 1 - ICU mortality (\%) according to the presence of: HAP risk factors, timing of infection, setting of hospital-acquired pneumonia (HAP) diagnosis, presence of non-fermenting Gram-negative bacilli (NFGNB) or de-escalation.

${ }^{*} p<0.05$ 
isolate in VAP in four countries. Of note, $P$. aeruginosa isolates predominated in Portugal ${ }^{15}$; in our study this pathogen was the second most frequent, followed by $A$. baumannii.

This high frequency of NFGNB and of resistant organisms, either MDR or XDR isolates, in our sample, is similar to European multicenter reports and is probably related to several factors. ${ }^{15,20}$ Firstly, $83 \%$ of patients in our study exhibited one or more risk factors for the emergence of resistant pathogens. Importantly, $75 \%$ of patients had antibiotic treatment in the previous 30 days before diagnosis. Secondly, our studied sample was characterized by a prolonged hospitalization stay, an ubiquitous use of several invasive devices, with a significant incidence of patients with immunosuppression (10/60, 16.7\%). Thirdly, although below the European average,$^{7}$ the overall consumption of antibacterial agents in Portugal remains high, particularly in the community. In addition, the consumption of extended spectrum antibiotics in our hospital (piperacillin-tazobactam, carbapenems and quinolones) are high. All these factors contribute to the hospital colonization pressure, i.e. the prevalence of colonized patients, leading to higher probability of drug resistant organism infection in the hospital, particularly by MRSA or A. baumannii. ${ }^{21,22}$

Most patients received empiric antibiotic therapy and $67 \%$ received combination therapy. Current guidelines recommend that the empiric treatment of HAP includes dual coverage for $S$. aureus and $P$. aeruginosa when risk factors, late-onset or septic shock are present. ${ }^{1}$ Adequacy of empiric antibiotic therapy was present in $65 \%$ of cases, probably related to our high rate of initial combination therapy. The de-escalation rate was low (18.3\%), although in line with current literature ranging between $10 \%$ and $38 \%{ }^{23-25}$ This is probably a consequence of the observed high rate of resistant organisms, which is in accordance with the literature $(<10 \%$ of de-escalation performed in case of MDR bacteria). ${ }^{23}$ Reduction of prevalence of MDR in the ICU (and in the hospital) is one of the cornerstones of antimicrobial stewardship programs. Optimizing identification and isolation of patients with multidrug-resistant microorganisms, performing regular epidemiological and microbiological monitoring and adopting rules for antimicrobial prescription, minimizes the development of resistance and antibiotic overuse, and improves patient outcomes. ${ }^{26}$

Regarding the outcome, we did not find differences in mortality according to the presence of appropriateness of initial empiric antibiotic therapy (Table 5). These results are probably related to the small number of studied patients (only 40 had microbiological data allowing interpretation of adequacy), and to the low mortality rate (only nine patients died in this sub-group). However, the literature shows that mortality rate is significantly higher in patients with inappropriate empirical treatment than in those with appropriate therapy. ${ }^{27,28}$ Despite our results, it must be reinforced that early microbiological samples should be performed in all critical patients with HAP, ideally before beginning antibiotic treatment. Of note, in clinical settings with high prevalence of MDR (as our ICU) this information is of paramount importance in order to promptly adequate the initial therapy (escalate, de-escalate or stop antibiotics). Negative results should be interpreted with caution. However, a negative result for NFGNM from a reliable respiratory sample is particularly significant, even in the clinical scenario of previous antibiotic treatment, given the association with a high negative predictive value. ${ }^{29}$ The presence of shock (either in or out of the ICU) seems to be associated with lower survival (Table 5). These results are consistent with the literature showing that septic shock constitutes a risk factor for mortality in critically ill patients. ${ }^{30-33}$ In addition, our study shows that mortality was significantly higher when HAP was the cause of ICU admission, in contrast to patients who acquired HAP after ICU admission - 32\% vs $8.6 \%$, respectively corresponding to a risk around five times higher, after age adjustment (adjusted OR of 5.2). Notably, this group of patients with non-ICU acquired HAP had higher levels of lactate and lower levels of P/F ratio. Recent medical literature shows that the risk of death increases by $2 \%$ per hour of delay of antimicrobial therapy. ${ }^{34}$ The prompt diagnosis of HAP and early initiation of empiric antibiotic therapy in the patient in the ICU, as opposed to the ward patient, can be an explanation for this significant outcome difference. A higher disease severity score of patients with non-ICU acquired HAP admitted to the ICU, as showed by SAPS II, may additionally explain the observed higher mortality.

The present study has some limitations. Firstly, this was a single-center study, therefore our results may not apply to other clinical settings; however, we underline that this was a prospective longitudinal study over a one-year period (513 patients followed), in a multi-purpose ICU of a tertiary hospital with a large case-mix; actually, to the best of our knowledge this study describes the largest sample of patients with HAP in an ICU setting in Portugal. Secondly, the absence of a gold-standard for the clinical diagnosis of HAP makes it difficult to make comparisons with other studies. However, we followed national guidelines for diagnostic criteria of $\mathrm{HAP}^{3}$ and excluded all cases where disagreement between investigators was present, conferring uniformity to the diagnostic criteria. Thirdly, the methodology used in our study (etiologic agent considered if isolated within a period of 48 hours of the HAP diagnosis) could lead to some restrictions regarding positive microbiological identification. However, we think that from a pragmatic point of view, this methodology reflects more adequately the current medical practice in most ICUs. In addition, a 48-hour period adequately describes the incubation period of the most common bacteria and viruses. Finally, the relatively small sample studied $(n=60)$ did not allow for a more specific analysis, such as distinct clinical characteristics in special sub-groups of HAP, as is the case of the elderly, trauma, COPD, diabetes, patients with neoplasia or detailed clinical characterization of patients according to bacteriological profile.

\section{CONCLUSION}

In this study, the annual rate of incidence of HAP in the ICU was 6.9 cases/1000 intubation-days. The presence of 
risk factors for drug resistant bacteria was very frequent and $S$. aureus was the most frequent etiologic agent. The de-escalation rate was low. Multidrug-resistant organisms were present in $45 \%$ of documented HAP. In patients with nonICU acquired HAP, the ICU mortality rate was around five times higher compared to ICU-acquired HAP.

This study did not receive any specific grant from funding agencies in the public, commercial, or not-for-profit sectors.

\section{OBSERVATIONS}

Some of the results of this study have been previously reported in the form of an abstract (32 ${ }^{\text {nd }}$ Congress of the Portuguese Society of Pneumology - 2016).

\section{PROTECTION OF HUMANS AND ANIMALS}

The authors declare that the procedures were followed according to the regulations established by the Clinical

\section{REFERENCES}

1. Torres A, Niederman MS, Chastre J, Ewig S, Fernandez-Vandellos P Hanberger $\mathrm{H}$, et al. International ERS/ESICM/ESCMID/ALAT guidelines for the management of hospital-acquired pneumonia and ventilatorassociated pneumonia: Guidelines for the management of hospitalacquired pneumonia (HAP)/ventilator-associated pneumonia (VAP) of the European Respiratory Society (ERS), European Society of Intensive Care Medicine (ESICM), European Society of Clinical Microbiology and Infectious Diseases (ESCMID) and Asociacion Latinoamericana del Torax (ALAT). Eur Respir J. 2017;50.

2. Kollef $\mathrm{MH}$, Bassetti $\mathrm{M}$, Francois $\mathrm{B}$, Burnham J, Dimopoulos G, Garnacho-Montero J, et al. The intensive care medicine research agenda on multidrug-resistant bacteria, antibiotics, and stewardship. Intensive Care Med. 2017;43:1187-97.

3. Froes F, Paiva JA, Amaro P, Baptista JP, Brum G, Bento H, et al. Documento de Consenso sobre pneumonia nosocomial. Rev Port Pneumol. 2007;13:419-86.

4. Muscedere JG, Day A, Heyland DK. Mortality, attributable mortality, and clinical events as end points for clinical trials of ventilator-associated pneumonia and hospital-acquired pneumonia. Clin Infect Dis. 2010;51:S120-5.

5. Kalil AC, Metersky ML, Klompas M, Muscedere J, Sweeney DA Palmer LB, et al. Executive Summary: Management of Adults With Hospital-acquired and Ventilator-associated Pneumonia: 2016 Clinical Practice Guidelines by the Infectious Diseases Society of America and the American Thoracic Society. Clin Infect Dis. 2016;63:575-82.

6. De Waele JJ, Akova M, Antonelli M, Canton R, Carlet J, De Backer $D$, et al. Antimicrobial resistance and antibiotic stewardship programs in the ICU: insistence and persistence in the fight against resistance. A position statement from ESICM/ESCMID/WAAAR round table on multi-drug resistance. Intensive Care Med. 2018;44:189-96.

7. Direção Geral de Saúde. Programa de prevenção e controlo de infeções e de resistência aos antimicrobianos da Direção Geral de Saúde 2017. [accessed $2019 \mathrm{Apr}$ 1]. Available from: https://www.sns.gov.pt/wpcontent/uploads/2017/12/DGS_PCIRA_V8.pdf.

8. Direção Geral de Saúde. Programa de prevenção e controlo de infeções e de resistência aos antimicrobianos. 2018. [accessed 2019 Apr 1]. Availablefrom:https://www.google.pt/url?sa=t\&rct=j\&q=\&esrc=s\&source =web\&cd=2\&ved=2ahUKEwjAnrjesqXiAhXtDmMBHR08ApUQFjABeg QIARAC\&url=https\%3A\%2F\%2Fwww.dgs.pt\%2 Fportal-da-estatisticada-saude $\% 2$ Fdiretorio-de-informacao $\% 2$ Fdiretorio-de-informacao $\% 2 F$ por-serie-1003038-pdf.aspx\%3Fv\%3D11736b14-73e6-4b34-a8e8 d22502108547\&usg=AOvVaw1rmORSMJXy73hNh8V81N5X

9. Center for Disease Control. Prevention Center for Disease Control, Pneumocococcal Disease. [accessed 2017 Dec 8]. Available from: https://www.cdc.gov/pneumococcal/clinicians/clinical-features.html.

10. Trouillet JL, Chastre J, Vuagnat A, Joly-Guillou ML, Combaux D, Dombret $\mathrm{MC}$, et al. Ventilator-associated pneumonia caused by potentially drug-resistant bacteria. Am J Respir Crit Care Med. 1998;157:531-9.

11. Magiorakos AP, Srinivasan A, Carey RB, Carmeli $Y$, Falagas ME
Research and Ethics Committee and to the Helsinki Declaration of the World Medical Association.

\section{DATA CONFIDENTIALITY}

The authors declare having followed the protocols in use at their working center regarding patients' data publication.

\section{CONFLICTS OF INTEREST}

All authors report no conflict of interest.

\section{FUNDING SOURCES}

This research received no specific grant from any funding agency in the public, commercial, or not-for-profit sectors.

Giske CG, et al. Multidrug-resistant, extensively drug-resistant and pandrug-resistant bacteria: an international expert proposal for interim standard definitions for acquired resistance. Clin Microbiol Infect. 2012;18:268-81.

12. Kadri SS, Adjemian J, Lai YL, Spaulding AB, Ricotta E, Prevots DR, et al. Difficult-to-treat resistance in gram-negative bacteremia at 173 US hospitals: retrospective cohort analysis of prevalence, predictors, and outcome of resistance to all first-line agents. Clin Infect Dis. 2018;67:1803-14

13. Niederman MS. De-escalation therapy in ventilator-associated pneumonia. Curr Opin Crit Care. 2006;12:452-7.

14. Masterton RG. Antibiotic de-escalation. Crit Care Clin. 2011;27:149-62.

15. Koulenti D, Tsigou E, Rello J. Nosocomial pneumonia in 27 ICUs in Europe: perspectives from the EU-VAP/CAP study. Eur J Clin Microbiol Infect Dis. 2017;36:1999-2006.

16. European Centre for Disease Prevention and Control. Annual Epidemiological Report 2016 - Healthcare-associated infections acquired in intensive care units; [accessed 2017 Dec 8]. Available from: https://ecdc.europa.eu/en/publications-data/healthcare-associatedinfections-acquired-intensive-care-units-annua.

17. Jones RN. Microbial etiologies of hospital-acquired bacterial pneumonia and ventilator-associated bacterial pneumonia. Clin Infect Dis. 2010;51:S81-7

18. Weber DJ, Rutala WA, Sickbert-Bennett EE, Samsa GP, Brown V, Niederman MS. Microbiology of ventilator-associated pneumonia compared with that of hospital-acquired pneumonia. Infect Control Hosp Epidemiol. 2007;28:825-31.

19. Callejo-Torre F, Eiros Bouza JM, Olaechea Astigarraga P, Coma De Corral MJ, Palomar Martinez M, Alvarez-Lerma F, et al. Risk factors for methicillin-resistant Staphylococcus aureus colonisation or infection in intensive care units and their reliability for predicting MRSA on ICU admission. Infez Med. 2016;24:201-9

20. Craven DE, Lei $Y$, Ruthazer R, Sarwar A, Hudcova J. Incidence and outcomes of ventilator-associated tracheobronchitis and pneumonia. Am J Med. 2013;126:542-9.

21. Merrer J, Santoli F, Appere de Vecchi C, Tran B, De Jonghe B, Outin H. "Colonization pressure" and risk of acquisition of methicillin-resistant Staphylococcus aureus in a medical intensive care unit. Infect Control Hosp Epidemiol. 2000;21:718-23.

22. Masse J, Elkalioubie A, Blazejewski C, Ledoux G, Wallet F, Poissy J, et al. Colonization pressure as a risk factor of ICU-acquired multidrug resistant bacteria: a prospective observational study. Eur J Clin Microbiol Infect Dis. 2017;36:797-805.

23. Rello J, Vidaur L, Sandiumenge A, Rodriguez A, Gualis B, Boque C et al. De-escalation therapy in ventilator-associated pneumonia. Crit Care Med. 2004;32:2183-90.

24. Vaz AP, Amorim A, Espinar MJ, Oliveira T, Pereira JM, Paiva JA. Resultados positivos do lavado broncoalveolar e das culturas quantitativas na suspeita da pneumonia tardia associada ao ventilador — estudo retrospectivo. Rev Port Pneumol. 2011;17:117-23. 
25. Souza-Oliveira AC, Cunha TM, Passos LB, Lopes GC, Gomes FA, Roder DV. Ventilator-associated pneumonia: the influence of bacterial resistance, prescription errors, and de-escalation of antimicrobial therapy on mortality rates. Braz J Infect Dis. 2016;20:437-43.

26. Doron S, Davidson LE. Antimicrobial stewardship. Mayo Clin Proc. 2011;86:1113-23.

27. Leone M, Garcin F, Bouvenot J, Boyadjev I, Visintini P, Albanese J, et al Ventilator-associated pneumonia: breaking the vicious circle of antibiotic overuse. Crit Care Med. 2007;35:379-85.

28. Chin T, Kushner B, Dersch-Mills D, Zuege DJ. Antibiotic utilization patterns in patients with ventilator-associated pneumonia: a Canadian context. Can J Infect Dis Med Microbiol. 2016:3702625.

29. Parrillo J, Dellinger E, Phillip R, editors. Critical care medicine: principles of diagnosis and management in the adult. 5th ed. Philadelphia: Elsevier; 2019.

30. Brun-Buisson C, Doyon F, Carlet J, Dellamonica P, Gouin F, Lepoutre A, et al. Incidence, risk factors, and outcome of severe sepsis and septic shock in adults. A multicenter prospective study in intensive care units. French ICU Group for Severe Sepsis. JAMA. 1995;274:968-74.

31. Goto T, Yoshida K, Tsugawa Y, Filbin MR, Camargo CA Jr, Hasegawa K. Mortality trends in U.S. adults with septic shock, 2005-2011: a serial cross-sectional analysis of nationally-representative data. BMC Infect Dis. 2016;16:294.

32. Puskarich MA, Trzeciak S, Shapiro NI, Arnold RC, Horton JM, Studnek JR, et al. Association between timing of antibiotic administration and mortality from septic shock in patients treated with a quantitative resuscitation protocol. Crit Care Med. 2011;39:2066-71.

33. Seymour CW, Gesten F, Prescott HC, Friedrich ME, Iwashyna TJ, Phillips GS, et al. Time to treatment and mortality during mandated emergency care for sepsis. N Engl J Med. 2017;376:2235-44.

34. Bloos F, Ruddel H, Thomas-Ruddel D, Schwarzkopf D, Pausch C, Harbarth S, et al. Effect of a multifaceted educational intervention for anti-infectious measures on sepsis mortality: a cluster randomized trial. Intensive Care Med. 2017;43:1602-12. 